\title{
Human chorionic gonadotrophin in CSF, not serum, predicts outcome in germinoma
}

\author{
Takanori Inamura, Shunji Nishio, Kiyonobu Ikezaki, Masashi Fukui
}

\begin{abstract}
Objectives-Some intracranial germinomas, which may contain syncytiotrophoblastic giant cells (STGCs), are associated with a mildly to moderately increased human chorionic gonadotropin (HCG) concentration in serum, and patients with such germinomas are thus treated more aggressively than those with "pure" germinoma. However, the patients with germinoma and detectable HCG in CSF but not in serum have been classified and treated similarly to those with "pure" germinomas. The outcome of these patients and the relavance of HCG in the CSF were analysed.

Methods-The outcomes of patients with germinoma and increased serum HCG concentration $(n=7)$ were compared with those of patients having detectable HCG titre in the CSF but not in the serum $(\mathrm{n}=5)$.

Results-Both groups in our series received similar treatments and also showed similar recurrence rates. The $40 \%$ recurrence rate in the group with HCG only in CSF did not correspond to the rate typical for "pure" germinoma: these tumours would be expected to have a better outcome. An additional patient whose CSF HCG were raised without increased serum HCG at recurrence is presented.

Conclusions-It is recommended that patients with an increased HCG concentration in CSF should be considered to have "HCG producing germinoma", and they should be treated and followed up accordingly.

(F Neurol Neurosurg Psychiatry 1999;66:654-657)
\end{abstract}

Keywords: intracranial germinoma; human chorionic gonadotrophin; germinoma with syncytiotrophoblastic giant cells

Dr Takanori Inamura,

Department of

Neurosurgery, Neurological

Institute, Faculty of

Medicine, Kyushu

University, 3-1-1 Maidashi,

Higashi-ku, Fukuoka,

812-8582 Japan. Telephone

008192642 5524; fax 0081

92642 5528; email

taka@ns.med.kyushu-u.ac.jp

Received 28 August and in revised form

23 November 1998

Accepted 26 November 1998

Among the various intracranial germ cell tumours, germinoma, the most common, has a favourable prognosis, reflecting recent advancements in radiotherapy and chemotherapy. A 10 year survival rate exceeding $90 \%$ has been reported. ${ }^{12}$ Intracranial germinomas that contain syncytiotrophoblastic giant cells (STGCs), referred to as germinomas with $\mathrm{STGCs}^{3-6}$, show a poorer survival rate than "pure" germinomas. ${ }^{2356}$ By contrast with choriocarcinomas, which show markedly increased human chorionic gonadotrophin (HCG) concentrations in serum and CSF, patients whose tumours are germinomas with STGCs tend to show a slight to moderate increase in HCG concentration in either serum (usually< $1000 \mathrm{mIU} / \mathrm{ml}$ ) or CSF. ${ }^{157}$ Because of their poorer prognosis, some authors have recommended more aggressive therapy for germinoma with STGCs than for "pure" germinoma. ${ }^{67}$ In previous reports, not all patients with germinoma had assays for HCG or HCG- $\beta$ performed in CSF. As a result, the patients with germinoma and detectable HCG in the CSF used to be classified and treated as having "pure" germinoma when their serum HCG concentrations were not increased. We studied the outcomes of patients with intracranial germinoma and HCG or HCG- $\beta$ in serum, or CSF, or both.

\section{Materials and methods}

Between 1980 and 1994, 19 patients with intracranial germinomas were treated at our hospital. Among them, the 13 patients studied here had increased HCG or HCG- $\beta$ concentrations in the serum or CSF. All patients were male, with an average age at onset of 19.1 (range 9-47) years. Eight tumours were located in the pineal region $(61.5 \%)$, three were in the suprasellar region $(23.1 \%)$, and two were in the basal ganglia $(15.4 \%)$. Nine patients were diagnosed histologically with germinoma, but no STGCs were found in any surgical specimens from these cases. Four patients were diagnosed clinically and radiologically with germinoma according to established criteria that include patient age, tumour site, CT or MRI features, and a rapid response to radiation therapy. ${ }^{89}$

The pretreatment HCG or HCG- $\beta$ concentration was determined in both serum and CSF in 12 patients. In one patient, HCG and
HCG- $\beta$ were measured in the serum and CSF during treatment. All cases were negative for $\alpha$-fetoprotein in the serum.

The patients were divided into two groups according to HCG and HCG- $\beta$ concentration in the serum and CSF: a serum positive group $(n=7)$ in which HCG or the HCG- $\beta$ subunit were increased in both serum and CSF; and a CSF positive group $(n=5)$ in which both HCG 
Table 1 Serum positive group

\begin{tabular}{|c|c|c|c|c|c|c|c|c|}
\hline Case & Age/sex & Site & $\begin{array}{l}\text { HCG serum/ } \\
C S F(\mathrm{mIU} / \mathrm{ml})\end{array}$ & $\begin{array}{l}\text { HCG } \beta \text { serum } / \\
C S F(n g / m l)\end{array}$ & $\begin{array}{l}\text { Initial } \\
\text { treatment }\end{array}$ & Recurrence & Treatment at recurrence & Latest follow up \\
\hline 1 & $13 / \mathrm{M}$ & $\mathrm{P}$ & $40 / 88$ & $0.41 / 1.5$ & $\mathrm{R}$ & - & - & $12 \mathrm{y} /$ alive \\
\hline 2 & $12 / \mathrm{M}$ & BG & $130 / 90$ & $3.5 / 6.3$ & $\mathrm{R}$ & - & - & $15 \mathrm{y} /$ alive \\
\hline 3 & $9 / \mathrm{M}$ & $\mathrm{S}$ & $78 / 96$ & $0.57 / 1.34$ & Chem & - & - & $7 \mathrm{y} /$ alive \\
\hline 4 & $13 / \mathrm{M}$ & $\mathrm{P}$ & $-/-$ & $0.3 / 2.3$ & Chem & 6 months; local & Cranial irradication & $2 \mathrm{y} /$ alive \\
\hline 5 & $16 / \mathrm{M}$ & $\mathrm{P}$ & $56 / 70$ & $0.54 / 0.78$ & $\mathrm{R}$ & 14 months; spinal & Spinal irradication & $4 \mathrm{y} /$ died of tumour \\
\hline 6 & $22 / \mathrm{M}$ & $\mathrm{P}$ & $6.9 / 22$ & $0.47 / 1.1$ & Chem & 5 y; local CSF HCG- $\beta(+)$, normal serum HCG- $\beta$ & Cranial irradication & $7 \mathrm{y} /$ alive \\
\hline 7 & $16 / \mathrm{M}$ & BG & $6.4 / 8.0$ & $0.4 / 0.9$ & Chem & 3 y; local & Cranial irradication & $7 \mathrm{y} /$ alive \\
\hline
\end{tabular}

$\mathrm{BG}=$ basal ganglia; $\mathrm{P}=$ pineal; $\mathrm{S}=$ suprasellar; $\mathrm{R}=$ radiotherapy (whole brain, $30 \mathrm{~Gy}$; local $20 \mathrm{~Gy}$ ); Chem=chemotherapy; HCG=human chorionic gonadotrophin; HCG- $\beta=$ human chorionic gonadotrophin $\beta$-subunit; $-/-=$ not tested.

and HCG- $\beta$ were negative in the serum but at least one was positive in the CSF. We compared these two groups for treatment and outcome. Follow up periods ranged from 2 to 15 years.

\section{Results}

All patients received radiotherapy, or chemotherapy, or both, using cisplatin or carboplatin with VP-16.

SERUM POSITIVE GROUP (TABLE 1)

Among these seven patients, the HCG concentration in the serum was raised in six patients, whereas HCG- $\beta$ was raised in the remaining patient (case 4). In six patients, HCG and HCG- $\beta$ concentrations in CSF were greater than those in serum. In the remaining patient (case 2), the HCG concentration in the serum exceeded than that in the CSF, but the HCG- $\beta$ concentration was greater in CSF than in serum.

Three patients received radiotherapy (whole brain, $30 \mathrm{~Gy}$; local, $20 \mathrm{~Gy}$ ) whereas four received chemotherapy. Among the three patients treated by radiotherapy, two (cases 1 and 2) have remained free from disease for 12 and 15 years, respectively. The remaining patient (case 5) developed spinal dissemination but remained disease free for 3 years after spinal irradiation until he died 4 years after the initial treatment from a rapidly growing but unverified tumour in the basal ganglia. Among the four patients treated with chemotherapy, three (cases 4, 6, and 7) developed local recurrences within 5 years after initial treatment. These were managed successfully by radiotherapy (whole brain, $30 \mathrm{~Gy}$; local, $20 \mathrm{~Gy}$ ), and disease free periods thereafter ranged from 2 to 4 years. In case 6 , in which both serum and CSF HCG- $\beta$ concentrations were assayed at recurrence, the CSF HCG- $\beta$ concentration was higher than that in serum. After radiotherapy, however, HCG- $\beta$ was no longer detectable in the CSF.

CSF POSITIVE GROUP (TABLE 2)

HCG and HCG- $\beta$ concentrations were determined before treatment in five patients, the
HCG and HCG- $\beta$ concentrations in CSF were greater than those in serum.

All patients received radiotherapy (whole brain, $30 \mathrm{~Gy}$; local, $20 \mathrm{~Gy}$, except for patient 11 , in whom the treatment was 50 Gy to the whole brain). Two patients developed spinal dissemination between 6 months and 2 years after initial treatment (cases 11 and 12). Two cases showed interesting courses for HCG and HCG- $\beta$ concentrations.

Patient 11 was an 11 year old male with a tumour in the pineal region. His HCG- $\beta$ concentration in serum was $0.19 \mathrm{ng} / \mathrm{ml}$ (normal range $<0.4 \mathrm{ng} / \mathrm{ml}$ ) whereas that in the CSF was $0.4 \mathrm{ng} / \mathrm{ml}$. He underwent a ventriculoperitoneal shunt for associated obstructive hydrocephalus and also received whole brain irradiation. Six months after initial treatment, he developed spinal dissemination of the tumour. HCG- $\beta$ concentrations in serum and in the $\mathrm{CSF}$ at that time were $0.14 \mathrm{ng} / \mathrm{ml}$ and 2.4 $\mathrm{ng} / \mathrm{ml}$, respectively. Spinal radiotherapy was given and the HCG- $\beta$ concentration in the CSF decreased. Two months after radiotherapy, massive intraperitoneal dissemination developed, and was considered to represent a metastasis via the ventriculoperitoneal shunt. At this time, the HCG- $\beta$ concentration in serum was $23.4 \mathrm{ng} / \mathrm{ml}$; that in CSF was 3.67 $\mathrm{ng} / \mathrm{ml}$.

Patient 12 was a 47 year old man with a tumour in the pineal region. Concentrations of HCG and HCG- $\beta$ in the CSF were 2.0 $\mathrm{mIU} / \mathrm{ml}$ and $0.86 \mathrm{ng} / \mathrm{ml}$ before initial treatment. After radiotherapy, the intracranial lesion disappeared from diagnostic images, but the HCG- $\beta$ concentration in the CSF did not decrease. Two years after initial treatment, recurrence appeared as spinal dissemination outside the field of irradiation. The recurrence was managed successfully by chemotherapy; and resulted in a disease free period that has lasted for 3 years.

ADDITIONAL CASE (TABLE 3)

Patient 13 was a male 16 year old with a tumour in the pineal region. Concentrations of

Table 2 CSF positive group

\begin{tabular}{|c|c|c|c|c|c|c|c|c|}
\hline Case & Age/sex & Site & $\begin{array}{l}\text { HCG serum } / C S F \\
(m I U / m l)\end{array}$ & $\begin{array}{l}H C G-\beta \operatorname{serum} / C S F \\
(n g / m l)\end{array}$ & $\begin{array}{l}\text { Initial } \\
\text { treatment }\end{array}$ & Recurrence & $\begin{array}{l}\text { Treatment at } \\
\text { recurrence }\end{array}$ & Latest follow up \\
\hline 8 & $25 / M$ & $S$ & $<0.1 / 1.0$ & $0.28 / 0.56$ & $\mathrm{R}$ & - & - & 8 years/alive \\
\hline 9 & $22 / \mathrm{M}$ & S & $1.2 / 3.3$ & $0.34 / 0.24$ & $\mathrm{R}$ & - & - & 6 years/alive \\
\hline 10 & $19 / \mathrm{M}$ & $\mathrm{P}$ & $<0.1 / 1.3$ & $<0.1 /<0.1$ & $\mathrm{R}$ & - & - & 3 years/alive \\
\hline 11 & $18 / \mathrm{M}$ & $\mathrm{P}$ & $-/-$ & $0.19 / 0.4$ & $\mathrm{R}$ & $\begin{array}{l}6 \text { months; spinal; normal serum HCG- } \beta \text {, CSF } \\
\text { HCG- } \beta(+)\end{array}$ & $\begin{array}{l}\text { Spinal irradication } \\
\text { chemotherapy }\end{array}$ & $\begin{array}{l}8 \text { years/died } \\
\text { glioblastoma }\end{array}$ \\
\hline 12 & $47 / \mathrm{M}$ & $\mathrm{P}$ & $2.0 / 2.0$ & $<0.1 / 0.86$ & $\mathrm{R}$ & $\begin{array}{l}8 \text { months; intraperitoneal; raised serum HCG- } \beta \\
24 \text { months; spinal }\end{array}$ & Chemotherapy & 6 years/alive \\
\hline
\end{tabular}

Abbreviations as in footnote of table 1. 


\begin{tabular}{|c|c|c|c|c|c|c|c|c|}
\hline Case & Age/sex & Site & $\begin{array}{l}\text { HCG serum } / C S F \\
(\mathrm{mIU} / \mathrm{ml})\end{array}$ & $\begin{array}{l}H C G-\beta \\
\text { serum } / C S F(n g / m l)\end{array}$ & $\begin{array}{l}\text { Initial } \\
\text { treatment }\end{array}$ & Recurrence & $\begin{array}{l}\text { Treatment at } \\
\text { recurrence }\end{array}$ & Latest follow up \\
\hline 13 & $16 / \mathrm{M}$ & $\mathrm{P}$ & $-/-$ & $-/-$ & $\mathrm{R}$ & $\begin{array}{l}5 \mathrm{y} \text {, spinal } \\
7 \mathrm{y} \text {, intracranial; normal serum HCG- } \beta \text {, CSF HCG- } \beta(+)\end{array}$ & Spinal irradication & $8 \mathrm{y} /$ died \\
\hline
\end{tabular}

Abbreviations as in footnote of table 1.

HCG and HCG- $\beta$ were not measured in either serum or CSF at initial treatment. After radiotherapy, the intracranial lesion disappeared from diagnostic images. Five years after initial treatment, recurrence appeared as spinal dissemination outside the field of irradiation. After spinal irradiation, the lesion disappeared from diagnostic images until 7 years after the initial treatment, when recurrence occurred as intracranial dissemination. Concentrations of HCG and HCG- $\beta$ in the CSF respectively were $22.5 \mathrm{mIU} / \mathrm{ml}$ and $2.47 \mathrm{ng} / \mathrm{ml}$ before initial treatment. Neither markers were in the positive range in the serum at the final recurrence. The patient died of tumour progression.

\section{Discussion}

The normal ranges for HCG/HCG- $\beta$ concentrations in CSF are unknown. Bagshawe et al have reported that the HCG concentrations in CSF correlate closely with those in serum, whereas the serum/CSF ratio of HCG ranged from 177 to 200 in patients with extracranial gonadotrophin producing tumours. ${ }^{10}{ }^{11}$ In addition, serum HCG concentrations in patients with gonadotrophin producing intracranial germ cell tumours have not been reported to be increased, whereas concentrations in CSF were raised. ${ }^{12}$ Concentrations of HCG and HCG- $\beta$ in the CSF in patients with intracranial germ cell tumours thus may indicate the existence of gonadotrophin producing cells in tumour tissues.

In this series, we divided our germinoma patients into two groups: a serum positive group according to HCG and HCG- $\beta$ concentration and a CSF positive group with detectable HCG or HCG- $\beta$ in CSF but no increase in the serum. According to previous reports, ${ }^{15-7}$ the serum positive group may be considered to have germinoma with STGCs, whereas the CSF positive group has been classified among "pure" germinoma cases based on negative serum findings. All patients in the CSF HCG positive group were fully treated with conventional radiotherapy, whereas some cases in the serum HCG positive group were not completely treated with conventional radiotherapy. Although all patients in the CSF positive group received complete conventional radiotherapy, the recurrence rate of $40 \%$ was much higher than that seen in patients with "pure" germinoma, who tend to show a better prognosis with only rare recurrences. ${ }^{125613}$ The CSF positive group therefore should not be classified with "pure" germinomas.

In the CSF positive group, the HCG or HCG- $\beta$ concentrations in the CSF were greater than those in the serum. In addition, in two recurrent cases (patients 6 and 11) and patient 13, CSF HCG- $\beta$ concentrations were greater than those in the serum, whereas serum
HCG- $\beta$ concentrations were in the normal range. Moreover, HCG- $\beta$ in patient 11 increased after intraperitoneal dissemination through a venticuloperitoneal shunt. For evaluating actual outcome in the CSF HCG positive group, comparison between this group and a CSF HCG negative group would be required. However, only three patients with germinoma with negative CSF HCG had measurements of both serum and CSF HCG. Although these three patients have shown no evidence of recurrence for up to 3 years of follow up, this small number is not sufficient for valid comparison. Because the importance of CSF HCG measurement has not been recognised, previous authors have not described cases according to the CSF HCG concentration, so suitable data for comparison are not available from other studies. As HCG and HCG- $\beta$ concentrations in CSF represent more reliable markers for intracranial tumours than those in the serum, greater accumulation of cases of intracranial germinoma with both serum and CSF HCG data are needed, and are expected to accrue.

Several authors have discussed the origin of HCG in germinomas. ${ }^{44-16}$ It has been demonstrated immunohistochemically in STGCs in some cases. However, in many cases in which no STGCs are found in surgical specimens, HCG concentrations are raised none the less. In such germinoma cases the increased HCG concentration in serum is usually a basis for diagnosing "germinoma with STGCs." In some reports, however, the germinoma cells themselves have shown immunoreactivity for HCG. ${ }^{15}{ }^{16}$ In our series no STGCs were found in the surgical specimens; the term "germinoma with STGCs" therefore is not an accurate description of tumours without histologically demonstrable STGCs. Because previously reported patients having germinoma with STGCs and our HCG positive patients with germinoma (patients with normal HCG concentrations in the serum but abnormally detectable HCG in the CSF) all showed similar outcomes, we think that patients with an increase in HCG in either serum or CSF should be referred to as having an "HCG producing germinoma" or "HCG secreting germinoma" as described by Sawamura et al, ${ }^{17}$ and therefore should be treated and followed up similarly.

This work was supported by grants from Ministry of Education, No 08407043, and No 09771044. We thank Miss Yoshie Hirosawa and Miss Takako Shiga for their valuable assistance.

1 Shirato H, Nishio M, Sawamura Y, et al. Analysis of long-term treatment of intracranial germinoma. Int $\mathcal{F}$ Radiat Oncol Biol Phys 1997;37:511-5.

2 Matsutani M, Sano K, Takakura K, et al. Primary intracranial germ cell tumors: a clinical analysis of 153 histologinial germ cell tumors: a clinical analysis of 153

3 Ho D, Liu H. Primary intracranial germ cell tumor. Cancer 1992;70:1577-84. 
4 Yamagami T, Handa H, Yamashita J, et al. An immunohistochemical study of intracranial germ cell tumours. Acto Neurochir (Wien) 1987;86:33-41.

5 Shibamoto Y, Takahashi M, Sasai K. Prognosis of intracranial germinoma with syncytiotrophoblastic giant cells treated by radiation therapy. Int $\mathcal{F}$ Radiat Oncol Biol Phys 1997;37:505-10.

6 Uematsu Y, Tsuura Y, Miyamoto K, et al. The recurrence of primary intracranial germinomas. I Neurooncol 1992;13 247-56.

7 Yoshida J, Sugita K, Kobayashi T, et al. Prognosis of intracranial germ cell tumours: effectiveness of chemotherapy
with cisplatin and etoposide (CDDP and VP-16). Acta Neurochir (Wien) 1993;120:111-7.

8 Shibamoto Y, Takahashi M, Abe M. Reduction of the radiation dose for intracranial germinoma: a prospective study. Br f Cancer 1994;70:984-9.

9 Shibamoto T, Oda Y, Yamashita J, et al. The role of cerebrospinal fluid cytology in radiotherapy planning for intracranial germinoma. Int $\mathcal{f}$ Radiat Oncol Biol Phys 1994;29: nial germ

10 Bagshawe K, Orr A, Rushworth A. Relationship between concentrations of human chorionic gonadotrophin in

11 Bagshawe K, Harland S. Immunodiagnosis and monitoring of gonadotrophin-producing metastases in the central

nervous system. Cancer 1976;38:112-8.
12 Allen J, Nisselbaum J, Epstein F, et al. Alfafetoprotein and human chorionic gonadotropin determination in cerebrospinal fluid. An aid to the diagnosis and management of intracranial germ-cell tumors. I Neurosurg 1979;51:36874

13 Jennings $M$, Gelman R, Hochberg F. Intracranial germ-cell tumors: natural history and pathogenesis. $\mathcal{f}$ Neurosurg 1985;63:155-67.

14 Laidler P, Pounder D. Pineal germinoma with syncytiotrophoblastic giant cells: a case with panhypopituitarism and sosexual pseudopuberty. Hum Pathol 1984;15:285-7.

15 Washiyama K, Sekiguchi K, Tanaka R, et al. Immunohistochemical study on AFP, HCG, and PLAP in primary intracranial germ cell tumors. Prog Exp Tumor Res 1987;30: 296-306.

16 Bjornsson J, Scheithauer B, Okazaki $\mathrm{H}$, et al. Intracranial germ cell tumors: pathobiological and immunohistochemical aspects of 70 cases. f Neuropathol Exp Neurol 1985;44:32-46.

17 Sawamura Y, Shirato $\mathrm{H}$, Ikeda $\mathrm{J}$, et al. Induction chemotherapy followed by reduced-volume radiation therapy for newly diagnosed central nervous system germinoma. $\mathcal{F}$ Neurosurg 1998;88:66-72. 